Please cite this article as:

Dell'Era C and Verganti R (2010).

Diffusion of product signs in industrial networks: the advantage of the trendsetter.

European Journal of Innovation Management, Vol. 13, No. 1, Pp. 81-99.

(DOI: 10.1108/14601061011013249) 


\title{
DIFFUSION OF PRODUCT SIGNS IN INDUSTRIAL NETWORKS: THE ADVANTAGE OF THE TREND SETTER
}

\author{
Claudio DELL'ERA \\ Department of Management, Economics and Industrial Engineering \\ Politecnico di Milano - Piazza L. da Vinci, 3220133 Milano Italy \\ Tel: +390223992798 \\ Fax: +3902 23994083 \\ claudio.dellera@polimi.it
}

Claudio Dell'Era is a research assistant in the Department of Management, Economics and Industrial Engineering at Politecnico di Milano, where he is also a contract professor of Innovation Management and a lecturer in Design Management and Project Management. He finished his Ph.D. in Management, Economics and Industrial Engineering in 2007. His thesis was entitled "Language Mining - Managing design driven innovation by capturing, interpreting, sharing and communicating knowledge on socio-cultural trends." He has published in leading international journals, including the Journal of Product Innovation Management, Long Range Planning, R\&D Management, the International Journal of Operations \& Production Management, the International Journal of Innovation Management and European Journal of Innovation Management. Claudio Dell'Era's paper that investigates the development of new services in turbulent environments won the Best Paper Award at the European Institute for Advanced Studies in Management International Product Development Management Conference in 2004.

\section{Roberto VERGANTI}

Department of Management, Economics and Industrial Engineering 
Politecnico di Milano - Piazza L. da Vinci, 3220133 Milano Italy

$$
\begin{gathered}
\text { Tel: +3902 } 23992770 \\
\text { Fax: +3902 } 23994083 \\
\text { roberto.verganti@ polimi.it }
\end{gathered}
$$

Roberto Verganti is Professor of Management of Innovation at the Politecnico di Milano, where he also serves as the Director of the MaDe In Lab, the laboratory for education in management of design and innovation. He is also a visiting professor of Design Management at the Copenhagen Business School. He is a member of the Board of the EIASM (the European Institute for Advanced Studies in Management), of the Editorial Board of the Journal of Product Innovation Management and of the Advisory Council of the Design Management Institute. He has published over 100 papers, including 45 papers in leading international journals (such as the Journal of Product Innovation Management, Management Science and the Harvard Business Review) and seven books. He was awarded the "Compasso d'Oro" in 2001 (the most prestigious design award in Italy) for the Italian Design System research project, for which he served as a member of the Scientific Organising Committee. His most recent book is Design-Driven Innovation, published by Harvard Business Press. 


\title{
DIFFUSION OF PRODUCT SIGNS IN INDUSTRIAL NETWORKS: \\ THE ADVANTAGE OF THE TREND SETTER
}

\begin{abstract}
Purpose

Nowadays, the strategic role of design is reinforced by the increased attention that customers pay to the aesthetic, symbolic and emotional values of products. These values can be communicated through the appropriate combination of product signs (such as form, colours, materials, and so on), which gives meaning to a product. Consequently, companies are investing substantial efforts in appropriate strategies for the development of product signs and languages. Firms must understand how knowledge about new products signs diffuses in industrial networks in order to be able to access and exploit it. Does the capability to propose new product trends allow companies to be recognized as innovators? Does the early adoption of product signs positively affect consumer preferences?
\end{abstract}

\section{Design/methodology/approach}

An empirical analysis was conducted on strategies regarding a specific type of product within the Italian furniture industry (namely, chairs). In particular, the article explores the roles played by furniture companies in the diffusion processes of product signs. Analysing approximately 300 chairs marketed by 35 leading Italian furniture manufacturers between 1996 and 2005, the article explores different strategies adopted in the diffusion processes of product signs.

\section{Findings}

The empirical results illustrate how trend setters are able to attain the best performance in terms of innovativeness and, in part, consumer preferences by 
forwarding new interpretations of existing material combinations starting at the early phases of diffusion.

\section{Originality/value}

The paper analyses the different roles played by companies in the diffusion processes of product signs and thus provides interesting insights regarding the exploitation of the industrial resources of companies.

\section{Paper classification}

Research paper

\section{Keywords}

Diffusion of innovation, Strategy of innovation, Product design, Product signs, Furniture industry 


\section{INTRODUCTION}

The increasingly important role played by design in today's business and academic arenas is demonstrated by the real explosion of scholars and companies that try to link design to innovation and competitive advantage. For example, a sector-independent study developed by the Design Council (2005) illustrates that investing in design pays off for UK businesses, as nearly half of the companies in which design is an integral part of business strategy have seen increases in turnover, profits, competitiveness and the overall quality of their products and services. Many articles published in Business Week about design demonstrate the increasing attention paid to this phenomenon. As described in the article "The power of design" by Bruce Nussbaum (Business Week; May 17, 2004), companies are increasingly investing in design as well as integrating design consultants into their innovation processes. Design plays a key role, not only in helping businesses become more profitable but also in creating better environments and communities for us in which to live. We will discuss in detail our interpretation of design in the theoretical background section of this article, but we underline from the outset that we are not only talking about design in terms of aesthetics. The following affirmation by the designer Terence Conran explains that design is not only aesthetics:

"Design is 98\% commonsense and 2\% that magic ingredient called aesthetics and sometimes style." (Design Council and CBI, 2002)

Many scholars have analysed the relationships between design, innovation and competitive advantage (Gemser and Leenders, 2001; Platt et al., 2001; Borja de Mozota, 2003; Boland and Collopy, 2004; Creusen and Schoormans, 2005; Hertenstein et al., 2005). Significant efforts in the recent literature have concentrated on investigating one 
specific approach to design, usually referred to as "user-centered design" (Chayutsahakij and Poggenpohl, 2002; Veryzer and Borja de Mozota, 2005), but this is not the only way for companies to leverage on design. That is, the aesthetic and symbolic values of products are becoming more and more important in the consumer choices, as demonstrated by several studies (Dumaine, 1991; Schmitt and Simonson, 1997; Bloch et al., 2003). The aesthetic and symbolic dimensions of a product are becoming particularly relevant not only in industries such as luxury or fashion but also in industries traditionally regulated by the so-called "evolution of technologies" (Trueman and Jobber, 1998; Ravasi and Lojacono, 2005; Rindova and Petkova, 2007). As a consequence, companies are investing greater amounts of resources in developing new designs for their products in order to make products more fashionable rather than more functional (Pesendorfer, 1995). Despite the fact that Apple, Nokia, Nintendo and Bang \& Olufsen, for example, operate in industries traditionally shaped by the emergence of new technologies, the success of their products is strongly connected to the prominent role played by aesthetic and symbolic aspects (Cillo and Verona, 2008). Although the approach to modelling the diffusion of a technology or a new consumer durable is very similar to that of aesthetic and symbolic innovations (Meade and Islam, 2006), the latter has not been completely addressed. A recent and intriguing piece of research developed by Cappetta et al. (2006) develops and tests a conceptual framework for the affirmation and evolution of stylistic innovation in the luxury fashion industry. The development of new design languages allows products to convey meanings and values to users.

This conveyance of meanings and values to users establishes a sort of dialogue with them. Different from "fashionable" or stylish products, very often semantic innovations demand profound changes in socio-cultural models, and, as a result, their diffusion takes time to achieve tangible success (Latour, 1987; Callon, 1991; Bijker and Law, 1994; 
Geels, 2004). It is possible to introduce radical innovations in meanings only through developing strong and specific capabilities in the comprehension and interpretation of social and cultural needs. The diffusion of socio-cultural models and, consequently, their impacts on the interpretation of design languages depend on many interactions between several stakeholders. Customer interpretations are in line with what is happening today and for this reason they can rarely provide interesting feedback in terms of radical changes (Gero and Kannengiesse, 2004). For this reason, it is particularly interesting to study the modalities that govern knowledge diffusion regarding product languages in industrial networks. The model of design discourse proposed by Verganti (2006) suggests that companies engage in dialogue with different actors to access the dispersed and tacit knowledge about socio-cultural trends and latent market needs. Companies must understand how knowledge about new product languages diffuses in industrial networks in order to be able to access and exploit it. Does the ability to propose new product design trends allow companies to be recognised as innovators? Are innovators also trendsetters and anticipators of future design languages? Does the early adoption of design languages increase consumer preferences? The analyses of different roles played by companies in the diffusion processes of product signs can provide interesting insights regarding the exploitation of industrial resources that surround manufacturing companies.

\section{THEORETICAL BACKGROUND AND RESEARCH QUESTIONS}

The research questions studied here emerged from two main bodies of literature. First of all, the article clarifies the basic concepts about the innovation of product signs, and then it focuses on the dynamics that characterise the diffusion processes of innovations. 


\subsection{Innovation of product signs}

Several studies developed in recent years underline the importance of the semantic dimension of a product by recognising its relationship with competitive advantage (Csikszentmihalyi and Rochberg-Halton, 1981; Krippendorff, 1989; Cooper and Press, 1995; Margolin and Buchanan, 1995; Lloyd and Snelders, 2003). While McDonaghPhilp and Lebbon (2000) use the terms "emotional domain", "soft design" and "soft function", Durgee (2001) speaks about "product soul”. Meanwhile, Marzano (2000) focuses on "product experience". The creation of new meanings allows companies to act on socio-cultural models or, less radically, modify the already-incorporated meanings in products. The role of the "look and feel" of people, places and things is underlined by Postrel (2003); she claims that the aesthetic and symbolic dimensions of a product are increasingly relevant in many industries for a company to be successful. As discussed by Hirschman (1982), symbolic innovations consist of the assignment of social meaning to a product (or reassignment of a new social meaning to an existing product), while technological innovations are those that spring from the addition or alteration of tangible features in a product that serve to distinguish it from prior models. In terms of cognitive terminology, a symbolic innovation is one that possesses different intangible attributes than it did in a previous stage. An intangible attribute is one that is associated with the object by consumers but that does not arise from the physical nature of the object itself. During the 1950's, there was substantial discussion concerning the symbolic aspects of products (Gardner and Levy, 1955; Levy, 1959). According to the scholars involved in that discussion, design should be applied to deal with the meanings that people attach to products through languages that can be used to convey those meanings. Gotzsch (1999) introduced the concept of symbolic value in opposition to the concept of functional value and proposed the following working definition: "some 
products include a symbol or a message that is subconsciously recognised by its customer. This subconsciously recognised symbol adds important value to the product as its user feels that the product really suits him". Sanders (1992) underlines the relationships between the success of a product and three specific factors, namely, usefulness, usability and desirability; the latter of these represents the communicative aspects of the product and the psychological aspects linked to the interpretation of the customer.

Verganti (2003) expands and elaborates the concept of form, suggesting a consideration of the symbolic and emotional values of a product in addition to product functionalities; see Figure 1. The product can be innovated by implementing new product signs and languages developed by designers. Consequently, the designer first must understand the socio-cultural context that surrounds customers and, second, translate these inputs into concrete product signs.

\section{Insert here Figure 1}

Analysing product form, Van Onck (1994 and 2000) classified possible product signs in terms of topology (colour, material, surface, form, texture and so on), mereology (continuity, interruptions, holes, boundaries, hierarchies, dimensions, orientation and so on) and morphology and morphogenesis (reflection, aggregation, separation, transformation and so on). More specifically, product languages can be defined as specific aggregation of product signs in order to convey precise meanings and values. The comprehension of new radical product meanings requires that users find new connections to their socio-cultural context and establish new patterns of interaction with products. Design-driven innovations allow for the development of products that are completely different from fashionable or stylish products, and as such, they may 
contribute to the definition of new aesthetic standards by proposing new interpretations of socio-cultural models. In other words, design driven innovations cannot be considered merely as answers to user needs but rather are the results of a dialogue with consumers in order to satisfy not only utilitarian needs but also symbolic end emotional requirements. As mentioned before, the diffusion of socio-cultural models and their consequent impacts on the interpretation of product signs depend on many interactions between several stakeholders. For this reason, it is particularly useful to introduce the principal literature contributions about the diffusion of innovation in order to analyse the modalities that govern knowledge flows about product signs.

\subsection{Diffusion of innovation}

The literature concerning the diffusion of innovation (DoI) is particularly rich and articulated considering that it has been a topic of practical and academic interest since the 1960s, when the pioneering works of Fourt and Woodlock (1960), Mansfield (1961), Floyd (1962), Rogers (1962), Chow (1967) and Bass (1969) faced various modelling and forecasting problems. The interest excited by these papers can be judged by the amounts of citations for these papers on ISI Web of Science (in October 2008), which were $119,481,12,1,355,67$ and 863 , respectively. The diffusion of innovation has been studied from different perspectives, including the economic, strategic, marketing, historical and sociological; the recent literature is characterised by the introduction of new interpretative and predictive models, such as the bandwagon (Abrahamson and Rosenkopf, 1997) and social contagion (Burt, 1987) that enrich wellknown frameworks such as the epidemic (Mansfield, 1961) and probit models (Davies, 1979). Many researchers have primarily focused on the diffusion of innovation among customers, while some studies show how the process of diffusion of new technologies between companies is basically characterised by two sequential phases. First, a market 
selects specific technological solutions and determines the success of a subset of products developed by "first mover" companies, and then "follower" companies, by interpreting market reactions and competitor choices, imitate those technological solutions (Mansfield, 1963; Rogers, 1995; Mahajan et al., 1990; Ruttan, 2000). One of the most influential theories about the diffusion of innovation is from Rogers (1995) and defines different categories of adopters on the basis of the moment at which they adopt the innovation. The diffusion of an innovation follows a normal distribution, and consequently, the corresponding cumulated curve describes an $S$ profile. In the introduction phase, diffusion happens very slowly because the adopters are not very familiar with the innovation; then, in the middle phase, adoption grows very quickly and spreads until it reaches the maturity phase, at which point innovation is largely diffused, and the adoption again grows very slowly along an asymptotic pattern of saturation. Rogers (1995) supposed that this curve can be approximated as Gaussian because the influence between adopters and new potential adopters progressively increases with the diffusion of the innovation; the activation of a peer network inside a social system stimulates adopters to persuade potential consumers that have not already experimented with the novelty. Similarly to many epidemic theories (Hägerstrand, 1967; Mansfield, 1963), Rogers (1995) introduced five different categories of adopters, namely, innovators, early adopters, early majority, late majority and laggards. Describing the dynamics that characterise the diffusion processes, Rogers (1995) radically differentiated the first two categories in comparison to the last three. Innovators are those actors more interested in new ideas and enter into dialogue with other industries; for this reason, their network is not limited to precise geographic boundaries. They play the role of gatekeeper by transferring innovations from one industry to another and from a local system to another. To develop this kind of activity, innovators require financial resources able to absorb some level of failure, important technical competences and an 
inherent propensity to risk. Early adopters are much more integrated in the local social system, as they are able to influence other potential adopters (i.e., opinion leadership). Their contribution to diffusion processes consists in facilitating the attainment of a critical mass. The contribution of the early majority is mainly connected to its the large number of consumers it involves, which activates several interconnections, while for the late majority, adoption is mainly connected to economic necessities and the increased pressure of surrounding networks. Finally, the laggards are more traditionalists; they have limited resources and/or are isolated in the local system of interconnections.

Many studies in the innovation field underline the importance of the first mover's strategy by identifying several reasons that can push companies to propose new interpretations of product signs on the market. These reasons can be divided in two main groups; the first one relates to the short-term horizon and aims to increase market profitability, while the second one concerns the long-term perspective and aims to create strategic assets that can be exploited in the future. First-mover companies can exploit the opportunity window during which they are temporary monopolists. Follower companies will imitate them, as early adopters can gain extra profits associated with higher sales volume and profit margin. Moreover, the first-mover strategy contributes to increasing the reputation and leadership of a company on the market and at the same time allows the company to market products with a higher premium price. By proposing new interpretations of product signs and languages earlier than their competitors, companies can develop a strong relationship with consumers and reinforce trust. Finally, the early adoption of emerging product signs and languages can be exploited to introduce lock-in actions; first-moving companies can propose new aesthetical solutions that, if successful, can become "standards" for their competitors and partners.

With these models in mind, we analyse the diffusion processes of product signs in industrial networks. The objective of analysing the role of companies in the diffusion 
processes of product signs can be specified in the following research question; see also Figure 2.

RQ1: Does participation in the early stages of diffusion processes of product signs in industrial networks allow companies to be recognised as innovators?

RQ2: Does participation in the early stages of diffusion processes of product signs in industrial networks allow companies to gain greater consumer preferences?

Insert here Figure 2

\section{RESEARCH METHOD}

In terms of empirical analysis, this article focuses on the Italian furniture industry for several reasons; first of all, furniture companies have developed numerous innovations in product signs. In 2002, Italy became the leading furniture-producing country in the EU, representing $26.3 \%$ of the total EU production; Italian manufacturers exported 8,960 million Euros worth of furniture in 2002. This article was developed thanks to a collaboration with Webmobili, which is an Internet spin-off of Federmobili, the Italian Association of Furniture Manufacturers; the Internet database developed by Webmobili (www.webmobili.it) was particularly appropriate for the research objectives here. Currently, the Webmobili database contains more than 19,000 products divided into 12 sections. It can be considered a good representation of the actual offering of the Italian furniture industry because it stores data on all companies that have an industrial 
structure. All products contained in the Webmobili database are described in terms of the name of the product, producer, designer, production year, materials, price range and awards. In addition to this information, the Webmobili database provides a photo and a brief description of the product in terms of its materials and surface treatments. The empirical analysis described in this paper focuses only on the Chairs section; more specifically, the sample is composed of 294 products developed and launched by 35 leading design companies during the 1996-2005 decade. While a product can be characterised by several product signs (material, colour, form and so on), the article focuses only on an analysis of different materials (recall that these materials can be seen and touched and as such do not refer to the internal parts of the products), since previous studies using the same database (Dell'Era et al., 2008; Dell'Era and Verganti, 2007) have determined that materials represent the most important and significant set of signs. Using the information provided by the Webmobili database, we have identified seven principal families of materials, namely, wood (W), straw (S), metal (M), polymer (P), fabric (F) and leather (L). Obviously, a chair can be composed of several materials, and for this reason, we have identified 19 different combinations of previous families of materials. For example, the Fpe chair designed by Ron Arad for Kartell in the 1997 is characterised by two specific materials, namely, aluminium belonging to the family of metals and polypropylene belonging to the family of polymers, and so these two material families represent an example of MP material combination.

\subsection{Analysing diffusion processes}

In order to analyse the diffusion processes of product signs in industrial networks, we first mapped the evolution across time of the adoption of specific combinations of materials. For example, in 1996, only $5.9 \%$ of new products were made of metal and polymer, while in 2001, the percentage increased to $36.4 \%$ (Figure 3 ). 
Insert here Figure 3

This initial analysis allowed us to identify two categories of combinations, namely, persistent and temporary combinations; see Table 1.

\section{Insert here Table 1}

At this point, we analysed the diffusion processes of different combinations of material families in the following way. Considering that temporary combinations represent localised solutions, we interpreted them as Explorations. In the case of persistent combinations, we adopted a different classification; more specifically, by taking into consideration the percentages of adoption of each combination in three different years $(\mathrm{t}-1, \mathrm{t}$ and $\mathrm{t}+1)$, we determined four different roles in the diffusion processes of product signs (Table 2). For example, we have classified as Trend Setting those products that in the year $t$ were characterised by combination $X$ and were able to invert a decreasing trend in relation to the previous year into an increasing trend in relation to the next year. This kind of classification did not allow us to analyse 61 chairs developed in 1996, as we did not have data on the previous year, or 2005, as we did not have data on the next year. Considering again the adoption of MP combinations described in Figure 3, we can conclude that chairs characterised by metal and polymer and launched on the market in 2000 should be classified as Trend Setting products, while chairs with similar characteristics presented on the market the following year must be classified as Participation to Majority. 
Obviously, a company can play different roles over time and in relation to different products. In order to identify the peculiar characteristics of each company strategy in terms of participation in the diffusion processes of product signs, we compared the profile of each company with the average profile exhibited by the entire sample (Table 2). The unique behaviour adopted by each company has been identified by selecting the greater percentage differences between each company profile and the average profile showed by the entire sample. In this way, we have identified six companies with a unique strategy called Explorer, seven companies with a Trend Setter strategy, eight companies with an Early Adopter strategy, eight companies with a Majority strategy and six companies with a Laggard strategy.

\subsection{Description of performance}

To analyse the reputation of each company in terms of innovativeness, we used the "Compasso d'Oro" award, which is the most prestigious acknowledgement dedicated to design with regard to products, research and merit; its international prestige is unquestioned. Established in 1954, the award is assigned by the Association for Industrial Design (ADI) with the purpose "to honour the merits of those entrepreneurs, craftsmen and designers who, in their work, by applying a new and particular artistic commitment, give their products such qualities of form and presentation as to make them unitary expressions of their technical, functional and aesthetic characteristics" ("Aims and Objectives of the Award", 1954). The "Compasso d'Oro" award is explicitly assigned to products that are considered particularly innovative in terms of design signs and languages. It oversees a pre-selection process determined by the Permanent Design Observatory in which a commission of design language experts (i.e., critics, historians, journalists, designers, architects, professors and others) continuously 
collects information, evaluates products and selects the best products. The jury of the "Compasso d'Oro" award is international and consists of more than five members randomly selected from a pool of qualified researchers and experts of several market industries.

To analyse consumer preferences, we analysed Webmobili visits. In recent years, the number of Internet users has exponentially increased; the diffusion of PCs and Internet connections has continuously expanded. The number of Internet users in Italy increased by approximately $8 \%$ from 2004 to 2005 , reaching a total of 20 million (Audiweb by Nielsen Net Ratings). In addition, the furniture industry is paying an increasing amount of attention to the Internet world. As mentioned before, Webmobili is an Internet spinoff of Federmobili, the Italian Association of Furniture Manufacturers; in the last 4 years, it has collected more than 400 catalogues of industrial companies in the Italian furniture industry. The success of this Internet portal was confirmed by data that rank Webmobili in the 100 most-visited Italian websites in 2004 and 2005. The Webmobili system counts visits to each product datasheet; we used these data to evaluate consumer preferences expressed in relation to each product. Although we cannot affirm that this kind of data can approximate the sales of each product, it does reveal the attractiveness of product semantic aspects. In this sense, we believe that data stored in the Webmobili database can be used to evaluate the consumer reactions generated by specific product signs. More specifically, to evaluate consumer preferences associated with each product, we have calculated the mean number of visits per day associated with each product sheet.

\section{EMPIRICAL RESULTS}


This article aims to determine whether early participation in the diffusion processes of product signs in industrial networks allows companies to be recognised as innovators and thus to better match consumer preferences. Consequently, this section is organised in two parts. First of all, we describe the strategies adopted by companies that have received (or have been selected for) the "Compasso d'Oro Award", and then we analyse the companies that best match consumer preferences in the context of diffusion processes.

\subsection{Companies recognised as innovators}

As mentioned previously, in order to analyse the strategy adopted by companies that are recognised as innovators in terms of proposition of new signs and languages, we analysed the "Compasso d'Oro" award. Excluding 61 chairs introduced in 1996 or 2005 that showed persistent combinations, only 37 products were considered as Trend Setting. Seven of these $(18.9 \%)$ have received or have been selected for the "Compasso d'Oro" award. Trend Setting products showed the best relationship between number of awards and number of products (Table 3). The Logit analysis described in Table 4 demonstrated that only Trend Setting products could be considered predictors of Innovativeness. The significant and positive relationship between these two variables indicated that participation in the early stages of diffusion processes of product signs in industrial networks, even if only in some cases and not only as a distinct strategy, allows companies to be recognised as innovators.

\section{Insert here Table 3 and Table 4}

It is interesting to note that explorations are rarely recognised as interesting innovations. One possible explanation is that in a consolidated industry such as the 
furniture sector, it is particularly difficult to re-interpret existing combinations of materials rather than to propose new ones; these re-interpretations are considered the most important innovations. Moving our attention to the company strategy adopted by each manufacturer, Table 3 shows that companies that mainly participated as trendsetters in the diffusion processes of material combinations ere strongly recognised as innovators. In fact, each company that participated in the diffusion processes as a trendsetter received on average 1.429 awards.

\subsection{Companies that match consumer preferences}

As described in the research method section, we used the visits to each product site on the Webmobili website to analyse the relationships between strategy in diffusion processes and consumer preferences. In this case, empirical results were less clear than in the case of companies recognised as innovators. Explorations and Trend Setting products gained less in terms of addressing consumer preferences in comparison to Participation to Majority and, in particular, Early Adoptions and Lag Participations (Table 5). At the same time, the linear regression described in Table 6 did not indicate significant relationships between consumer preferences and potential predictors.

\section{Insert here Table 5 and Table 6}

Interesting patterns emerged by considering the company strategy adopted by each company in the diffusion processes. Majority showed the best performance; on average, each company belonging to this category received the greatest number of visits per product per day (0.67). At the same time, Laggards represented the worst performers (0.36). Trend Setters and Early Adopters showed medium-high performances, but both were characterised by high values of standard deviation. In other words, these two 
groups were composed of companies that reached a level of performance different in terms of consumer preferences. Trend Setting companies were also able to gain high consumer approval even if their products could not be considered Trend Setting; that is, they were able to propose new product signs, but they could also implement and improve material combinations proposed by other companies to obtain greater consumer approval.

Twelve manufacturers $(34.3 \%)$ belonged to the group of "innovators", as they have received or have been selected for at least one "Compasso d'Oro" award, while 16 firms (45.7\%) belonged to the group of "successful companies", since the average number of visits gained by their products were higher than the total mean. In order to verify the relationships between these two levels of performance, we used cross innovativeness and consumer preferences to obtain four different company positions:

- Innovative Leader: these were innovative companies that received or been selected for the "Compasso d'Oro" award and match consumer desires and needs.

- Design Niche: these are companies that were considered particularly innovative but were not able to reach a significant success in terms of consumer approval. Their offerings were too innovative, and Webmobili visitors were probably not able to comprehend the meanings associated with these new product signs.

- Market Oriented: although these companies were not considered particularly innovative, they matched consumer expectations by interpreting actual product trends.

- Ineffective and Sleeper: these companies imitated established product signs and were not able to obtain significant success in terms of consumer preferences. 
If we calculate the percentage composition of products developed in each category of companies in terms of Exploration, Trend Setting, Early Adoption, Participation to Majority and Lag Participation, interesting patterns emerge (Figure 4). Empirical results allowed us to determine that the approach of Innovative Leaders was characterised by a strong participation in diffusion processes beginning in the early stages; in fact, they include the highest percentages of Trend Setting (20.0\%) and Early Adoptions (14.5\%). Design Niche companies showed a profile very similar to the general one; they placed greater emphasis on Explorations by introducing several temporary combinations of materials $(12.5 \%)$, and at the same time, they were late in the introduction of new interpretations of persistent combinations (18.9\%). Market Oriented companies mainly participate in diffusion processes as part of the majority (47.1\%), but their capabilities in terms of interpreting market needs and desires allowed them also to set new trends (18.6\%). Finally, Ineffective and Sleeper companies showed the highest values of Lag Participation (19.7\%).

\section{Insert here Figure 4}

Figure 5 describes the composition of each category of companies according to the strategy they adopt in the diffusion processes of product signs. For example, the set of seven Innovative Leaders was composed of three Trend Setters (42.9\%), two Early Adopters (28.6\%), one Majority Participator (14.3\%) and one Laggard (14.3\%). It was quite difficult to identify clear polarisations, but we could note, for example, the absence of Explorers within Innovative Leaders and the absence of Trend Setters within Ineffective and Sleepers. 


\section{CONCLUSIONS}

As previously mentioned, the model of the design discourse proposed by Verganti (2006) posits that companies dialogue with different actors to access dispersed and tacit knowledge on socio-cultural trends and latent market needs. Several other studies (Levy, 1959; Hirschman, 1982; Trueman and Jobber, 1998; Verganti, 2003; Ravasi and Lojacono, 2005; Rindova and Petkova, 2007) considered that the knowledge on subtle and unexpressed dynamics of socio-cultural models is distributed and tacit, and so the introduction of innovations of product signs and meanings requires the development of specific capabilities in order to access tacit and distributed knowledge and thus proactively participate in discussions on socio-cultural models and values emerging in society. The diffusion and success of product signs depend on several types of interactions among different stakeholders, including users, firms, designers, products, communication media, cultural centres, schools, and artists. Companies must understand how knowledge about new product languages diffuses in industrial networks in order to be able to access and exploit it. Analysis of the different roles played by companies in the diffusion processes of product signs can provide interesting insights in the exploitation of industrial resources used by manufacturing companies. The empirical results shown here indicated that the participation in the early stages of the diffusion processes of product signs in industrial networks allows companies to be recognised as innovators (Table 4), while consumer preferences capture different phenomena. More specifically, the linear regression described in Table 6 did not indicate a significant relationship between consumer preferences and the role played by companies in diffusion processes. If Trend Setting products show medium-low consumer approval, Trend Setters are able to gain a high level of consumer approval for those products that 
cannot be considered Trend Setting; they are able to propose new product signs as well as implement and improve material combinations proposed by other companies obtaining greater consumer preferences.

Innovative Leaders were characterised by a proactive strategy in the diffusion processes of products signs. They avoided introducing many explorative aesthetical solutions; they showed the lowest value of Exploration (10.9\%), and at the same time, they focused on the reinterpretation of persistent combinations that set new trends beginning with the early phases of diffusion processes. The Innovative Leader category showed the highest values for both Trend Setting (20.0\%) and Early Participation (14.5\%). In contrast, Design Niche companies focused their strategy on the exploration of new material combinations, as they showed the highest value of Exploration $(12.5 \%)$; this kind of approach allows them to be recognised as innovators, but it pushes them to be late in the diffusion processes of persistent combinations and does not favour the interpretation of consumer desires, as $18.8 \%$ of their products can be classified as Lag Participation. Market Oriented companies showed an intriguing profile; they exhibited the lowest values of Early Adoption and Lag Participation. On the one hand, they matched consumer preferences and showed that it was important to propose new interpretations of persistent combinations. In fact, they developed several Trend Setting products in comparison to the general profile (18.6\%). On the other hand, they concentrated their strategy on the introduction of many products, as indicated by the number of Participation to Majority (47.1\%) products in order to avoid being too "late"; note that Lag Participation products only account for $15.7 \%$ of the total here. Finally, Ineffective and Sleeper companies are characterised by the highest values of Participation to Majority (47.4\%) and Lag Participation (19.7\%). They also showed the lowest value of Trend Setting products $(10.5 \%)$, confirming that in order to match consumer preferences and to be recognised as innovators, it is important to propose new 
interpretations of persistent combinations. From a managerial perspective, the empirical results can support companies as they identify alternative strategies in order to pursue different performances. Trendsetters, by proposing new interpretations of existing material combinations on the market beginning in the early phases of diffusion processes, are recognised as innovators and are thus able to achieve high consumer approval even for those products that cannot be considered trend setting themselves. In other words, participation in the early stages of the diffusion processes can improve brand value and consequently increase consumer approval.

However, this research has some limitations. Even if representative of the national market, the database did not contain all products offered by Italian chairs manufacturers. Moreover, the article analysed only a set of product signs, which did not necessarily reflect the categorisation schemes adopted by consumers. This article has posed further research questions that merit future developments. It is necessary to verify its external validity, as the data refer to a specific section of the Italian furniture industry. Although signs of innovation in other industries are also important, the presence of similar phenomena still must be empirically tested. Other research paths are also possible, such as the analysis of diffusion processes in different furniture sections. The Webmobili database indeed allows us to analyse the role of designers in the diffusion of product signs; for example, we can verify if large designer portfolios allow companies to be more innovative In addition, the study of the geographic dimension (that is, by considering company address provided by Webmobili database) can allow us to analyse imitative and cooperative phenomena between clusters of companies situated in the same region. 


\section{ACKNOWLEDGMENTS}

The authors would like to acknowledge the managers of Webmobili, Ultimo Politi, Lara Bezzecchi and Gianluca Cislaghi and the researchers at the Politecnico di Milano and in particular Alessio Marchesi, whose contribution was tireless and invaluable throughout the research process. Naturally, any mistakes or omissions are the sole responsibility of the authors. Financial support from the FIRB fund "ART DECO Adaptive InfRasTructures for DECentralized Organizations" is also gratefully acknowledged. 


\section{REFERENCES}

Abrahamson E and Rosenkopf L. (1997). Social network effect on the extent of innovation diffusion: a computer simulation Organization Science, Vol. 8, No. 3, Pp. 289-309.

Bass FM. (1969). A new product growth model for consumer durables. Management Science, Vol. 15, Pp. 215-227.

Bijker WE and Law J (1994). Shaping Technology / Building Society. Studies in Sociotechnical Change. Cambridge, Massachusetts: The MIT Press.

Bloch PH, Frederic FB and Todd JA (2003). Individual Differences in the Centrality of Visual Product Aesthetics: Concept and Measurement. Journal of Consumer Research, Vol. 29 (March), Pp. 551-565.

Boland RJ and Collopy F. (2004). Managing as Designing. Stanford University Press.

Borja De Mozota B. (2003). Design Management - Using Design to Build Brand Value and Corporate Innovation. Allworth Press.

Burt RS. (1987). Social contagion and innovation: cohesion versus structural equivalence. The American Journal of Sociology, Vol. 92, No. 6, Pp. 1287-1335.

Callon M (1991). Techno-economic networks and irreversibility. In Law J (Eds.). A sociology of monsters: essays on power, technology and domination. Routledge, London, Pp. 132-161.

Cappetta R, Cillo P and Ponti A (2006). Convergent designs in fine fashion: An evolutionary model for stylistic innovation. Research Policy, Vol. 35, Pp. 1273-1290.

Chayutsahakij P and Poggenpohl S. (2002). User-Centered Innovation: The Interplay between User-Research and Design Innovation. Proceedings of The European Academy of Management $2^{\text {nd }}$ Annual Conference on Innovative Research in Management EURAM, Stockholm, Sweden. 
Chow GC. (1967). Technological change and demand for consumers. American Economic Review, Vol. 57, Pp. 1117-1130.

Cillo P and Verona G (2008). Search Styles in Style Searching: Exploring Innovation Strategies in Fashion Firms. Long Range Planning, Vol. 41, No. 6, Pp. 650-671.

Cooper R and Press M. (1995). The design agenda. John Wiley and Sons, Chicester UK.

Creusen MEH and Schoormans JPL. (2005). The Different Roles of Product Appearance in Consumer Choice. Journal of Product Innovation Management, Vol. 22, Pp. 63-81.

Csikszentmihalyi M and Rochberg-Halton E. (1981). The Meaning of Things: Domestic Symbols and the Self. Cambridge: Cambridge University Press.

Davies S. (1979). The diffusion of process innovation. Cambridge: Cambridge University Press.

Dell'Era C and Verganti R (2007). Strategies of Innovation and Imitation of Product Languages. Journal of Product Innovation Management, Vol. 24, Pp. 580-599.

Dell'Era C, Marchesi A, Verganti R and Zurlo F (2008). Language Mining: Analysis of the Innovation of Dominant Product Languages in Design-Intensive Industries. European Journal of Innovation Management, Vol. 11, No. 1, Pp. 25-50.

Design Council (2005). Design in Britain 2004-2005.

Design Council and CBI (2002). Competitive advantage through design.

Dumaine B (1991). Design that Sells and Sells and .... Fortune, Vol. 11 (March), Pp. $56-61$.

Durgee J. (2001). Soul branding: How to do it. Design Management Journal, Winter.

Floyd A. (1962). Trend forecasting: A methodology for figure of merit. In J. British (Ed.), Technological forecasting for industry and government (Pp. 95-105). New Jersey: Prentice Hall. 
Fourt LA and Woodlock JW. (1960). Early prediction of early success of new grocery products. Journal of Marketing, vol. 25, Pp. 31-38.

Gardner BB and Levy SJ (1955). The Product and the Brand. Harvard Business Review, March-April, Pp. 33-39.

Geels FW (2004). From sectoral systems of innovation to socio-technical systems. Insights about dynamics and change from sociology and institutional theory. Research Policy, Vol. 33, Pp. 897-920.

Gemser $G$ and Leenders M. (2001). How integrating industrial design in the product development process impacts on company performance. Journal of Product Innovation Management, Vol. 18, Pp.28-38.

Gero JS and Kannengiesse U. (2004). The situated function-behaviour-structure framework. Design Studies, Vol. 25, Pp. 373-391.

Gotzsch J (1999). Creating products with symbolic value. 3rd European academy of Design Conference, Sheffield March 30-April 01.

Hägerstrand T (1967). Innovation Diffusion as a Spatial Process. Chicago, University of Chicago Publications.

Hertenstein JH, Platt MB, Veryzer RW. (2005). The Impact of Industrial Design Effectiveness on Corporate Financial Performance. Journal of Product Innovation Management, Vol. 22, Pp. 3-21.

Hirschman EC (1982). Symbolism and Technology as Sources for the Generation of Innovations. Advances in Consumer Research, Vol. 10, Association for Consumer Research.

Krippendorff K. (1989). On the Essential Contexts of Artifacts or on the Proposition that «design is Making Sense (of Things)». Design Issues, Vol. 5, No. 2, Spring, 9-38.

Latour B (1987). Science in action: how to follow scientists and engineers through society. Harvard University Press, Cambridge, MA. 
Levy SJ (1959). Symbols for Sale. Harvard Business Review, Vol. 37 (July-August), Pp. 117-124.

Lloyd P and Snelders D. (2003). What was Philippe Starck thinking of? Design Studies, Vol. 24, Pp. 237-253.

Mahajan V, Muller E and Bass F. (1990). New product diffusion models in marketing: A review and directions for future research. Journal of Marketing, Vol. 54, Pp. 1-26.

Mansfield E. (1961). Technical change and rate of imitation. Econometrica, Vol. 29, Pp. 741-766.

Mansfield E. (1963). The speed of response of firms to new techniques. Quarterly Journal of Economics, Vol. 77, Pp. 290-311.

Margolin V and Buchanan R. (1995). The Idea of Design: A Design Issues Reader. Cambridge: MIT Press.

Marzano S. (2000). Suffusing Design Through the Organisation. Design Management Journal, Winter.

McDonagh-Philp D and Lebbon C. (2000). The emotional domain in product design. The Design Journal, vol. 3, pp. 31-43.

Meade N and Islam T (2006). Modeling and forecasting the diffusion of innovation - a 25 year review. International Journal of Forecasting, Vol. 22, No. 3, Pp. 519-545.

Pesendorfer W (1995). Design innovation and fashion cycles. The American Economic Review, Vol. 85, Pp. 771-792.

Postrel V (2003). The Substance of Style. Harper Collins Publishers, New York.

Platt MB, Hertenstein JN, David RB (2001). Valuing Design: Enhancing Corporate Performance through Design Effectiveness. Design Management Journal, Vol. 12, No. 3, Pp. 10-19, Summer.

Ravasi D and Lojacono G (2005). Managing design and designers for strategic renewal. Long Range Planning, Vol. 38, Pp. 51-77. 
Rindova VP and Petkova AP (2007). When is a new thing a good thing? Technological change, product form design, and perceptions of value for product innovations. Organization Science, Vol. 18, No. 2, Pp. 217-232.

Rogers EM. (1962). Diffusion of innovations, The Free Press: New York.

Rogers EM. (1995). Diffusion of innovations (Forth Edition), The Free Press: New York.

Ruttan VW. (2000). Technology adoption, diffusion, and transfer", in Technology, growth, and development: An induced innovation perspective, Oxford University Press: New York.

Sanders EB (1992). Converging perspectives: Product development research for the 1990s. Design Management Journal, Pp. 49-54.

Schmitt B and Simonson A (1997). Marketing Aesthetics: The Strategic Management of Brands Identity and Image. Free Press, New York.

Schumpeter JA (1942). The Theory of Economic Development. Cambridge: Harvard College.

Trueman M and Jobber D (1998). Competing through design. Long Range Planning, Vol. 31, Pp. 594-605.

Van Onck A. (1994). Design. Il senso delle forme dei prodotti. Lupetti Editori di Comunicazione, Milano.

Van Onck A. (2000). Semiotics in design practice. Design plus research, Proceedings of the Politecnico di Milano Conference, May 18-20.

Verganti R. (2003). Design as brokering of languages: The role of designers in the innovation strategy of Italian firms. Design Management Journal, (3): pp. 34-42.

Verganti R. (2006). Innovating through design. Harvard Business Review, December 2006. 
Veryzer RW and Borja de Mozota B. (2005). The Impact of User-Oriented Design on New Product Development: An Examination of Fundamental Relationships. Journal of Product Innovation Management, Vol. 22, Pp. 128-143. 


\section{FIGURES}

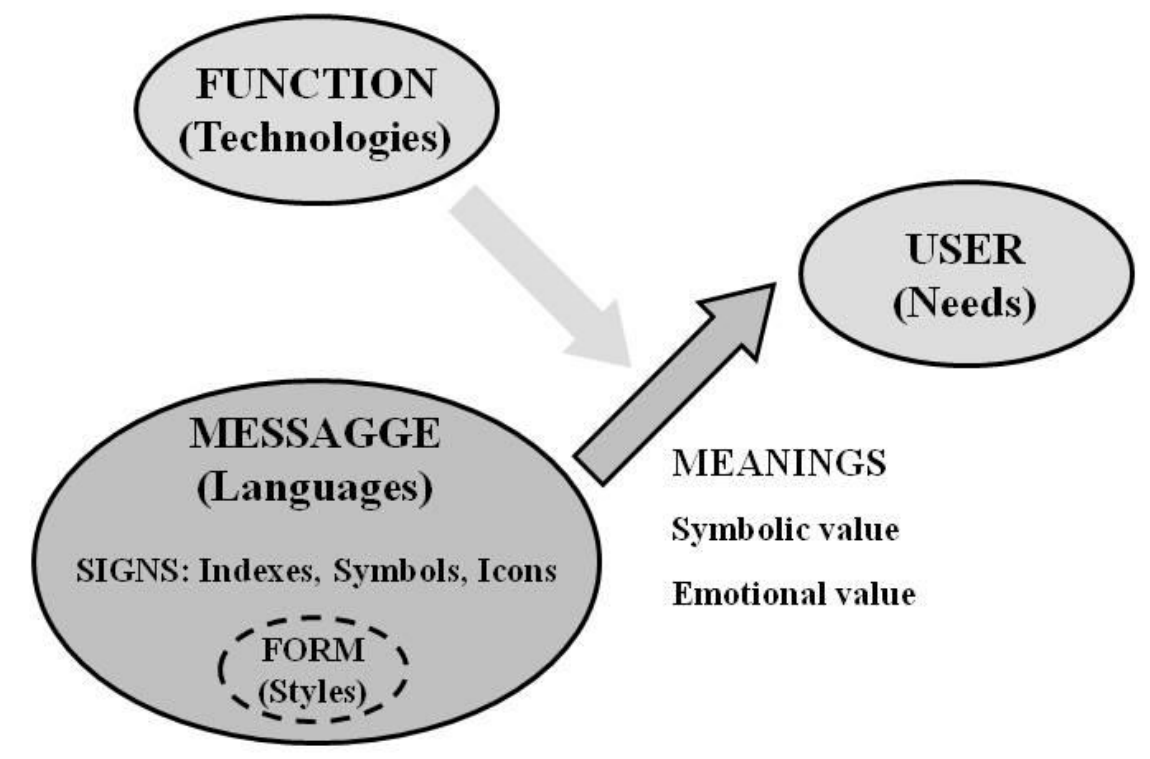

Figure 1: Design driven innovation (adapted from Verganti, 2003)

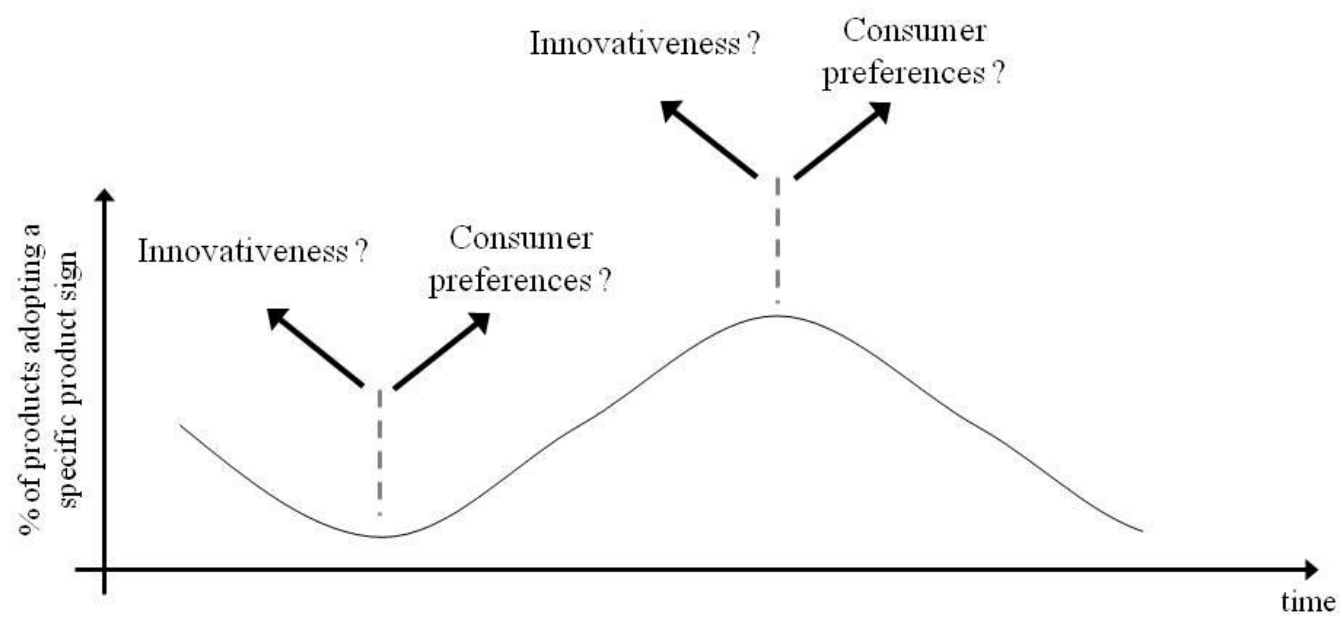

Figure 2: Research questions 


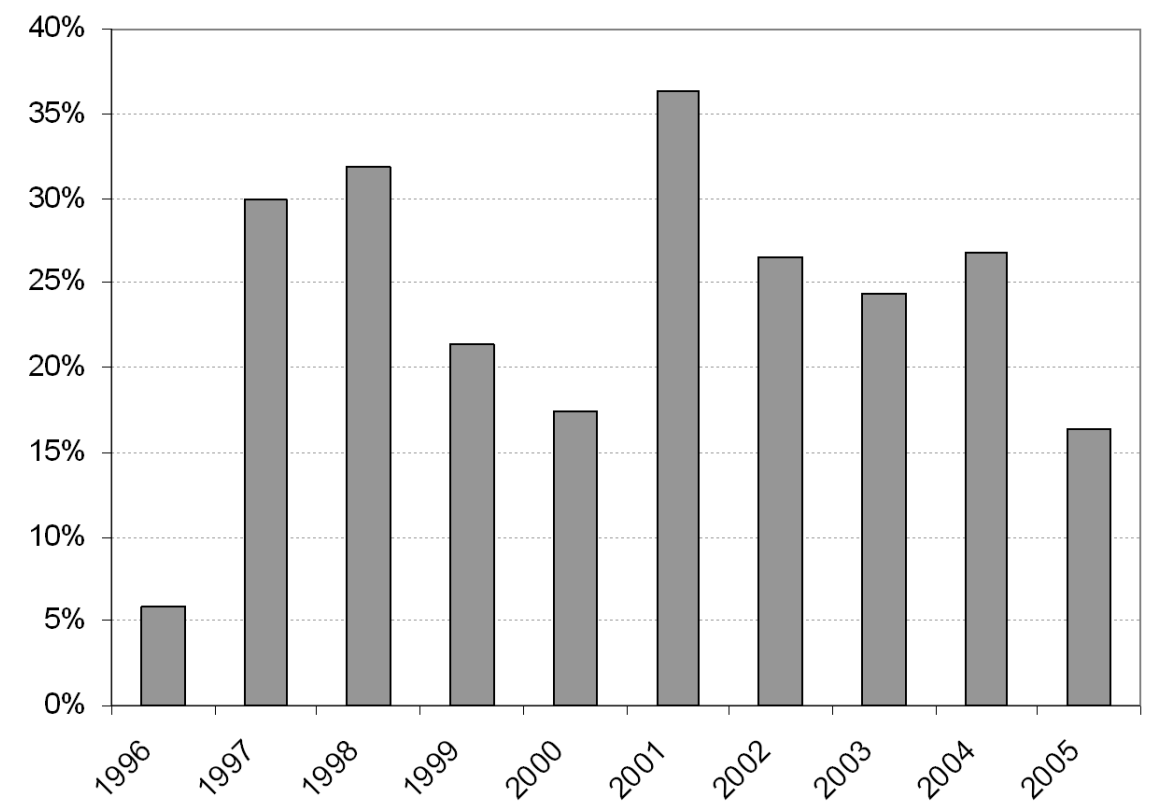

Figure 3: Adoption of MP combination across time

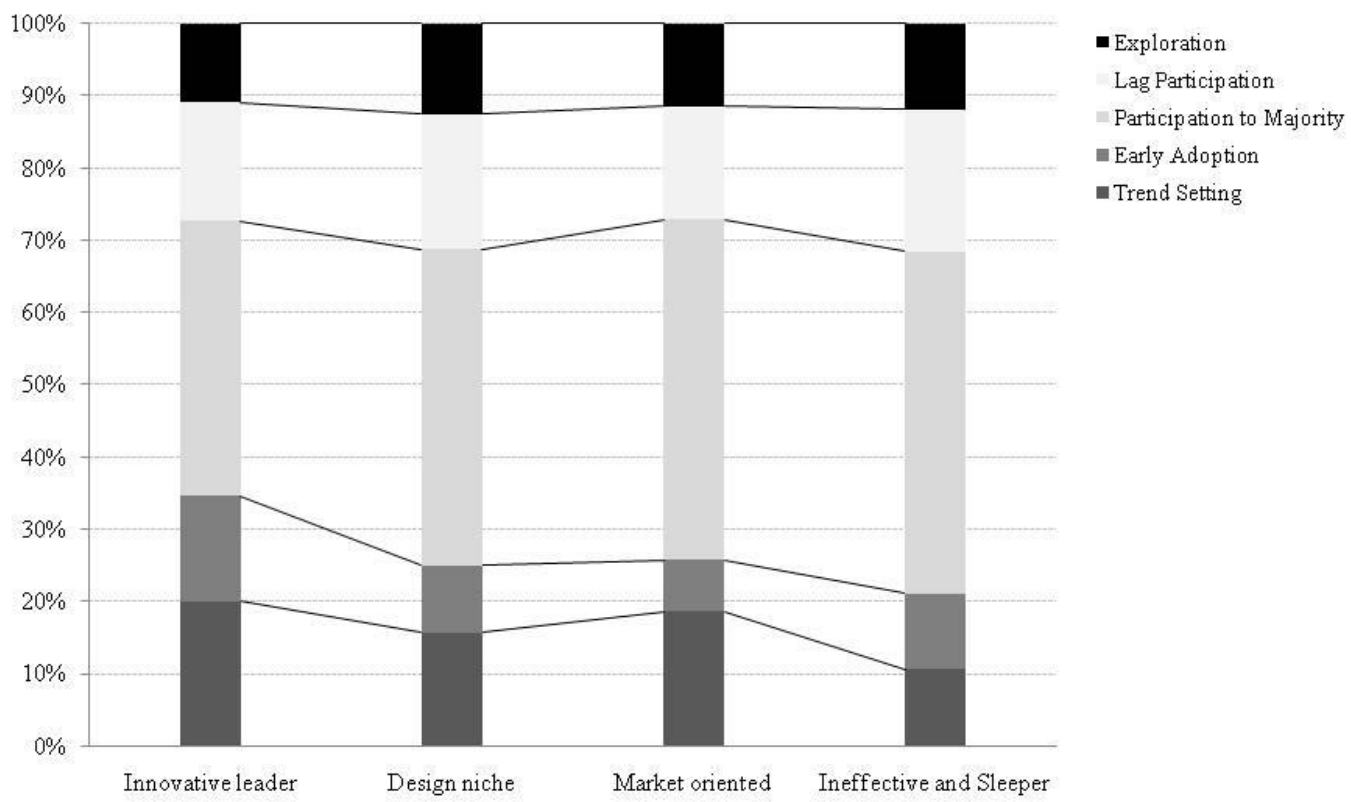

Figure 4: Product classification and performances 


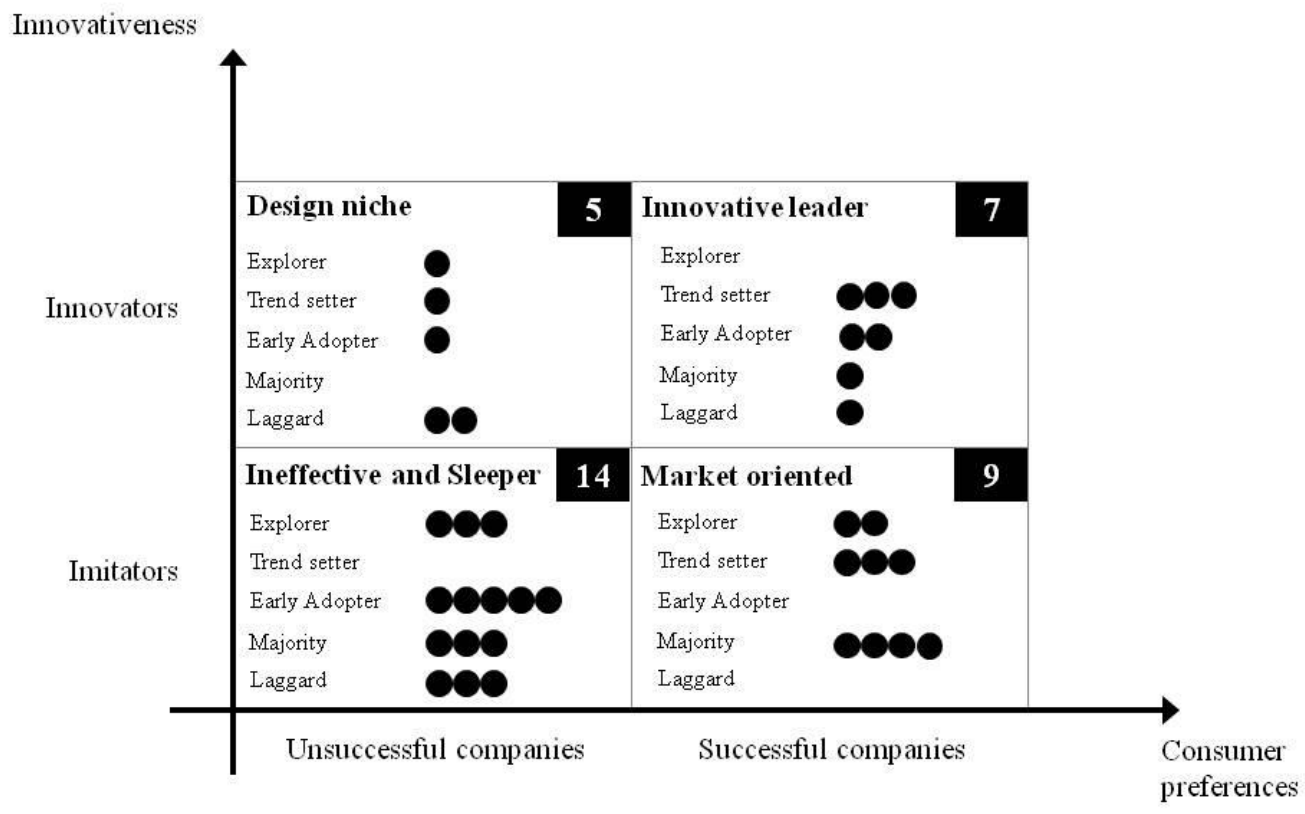

Figure 5: Company strategies and performances 


\section{TABLES}

\begin{tabular}{|l|c|c|}
\hline Definition & $\begin{array}{c}\text { Persistent combinations } \\
\text { Combinations of material families } \\
\text { that are present for more than 5 } \\
\text { years }\end{array}$ & $\begin{array}{c}\text { Combinations of material families } \\
\text { that are present for less than or } \\
\text { equal to 5 years }\end{array}$ \\
\hline List of combinations & $\begin{array}{c}\text { MP, MF, P, W, L, ML, WL, F, } \\
\text { WM, WF }\end{array}$ & $\begin{array}{c}\text { M, SM, WS, S, PF, SMF, WMF, } \\
\text { WML, WSF }\end{array}$ \\
\hline Number of combinations & 10 & 9 \\
\hline $\begin{array}{l}\text { Number of products } \\
\text { (percentage) }\end{array}$ & 267 & 27 \\
$(90.8 \%)$ & $(9.2 \%)$ \\
\hline
\end{tabular}

Table 1: Persistent and temporary combinations

\begin{tabular}{|c|c|c|c|c|}
\hline & Combination & $\begin{array}{l}\% \text { Comb X }(\mathrm{t})- \\
\% \text { Comb X }(\mathrm{t}-1)\end{array}$ & $\begin{array}{c}\% \text { Comb X }(\mathrm{t}+1)- \\
\% \text { Comb X (t) }\end{array}$ & $\begin{array}{l}\text { Number of } \\
\text { products } * \\
\text { (percentage) }\end{array}$ \\
\hline Trend Setting & Persistent & - & + & $29(12.6 \%)$ \\
\hline Early Adoption & Persistent & + & + & $24(10.3 \%)$ \\
\hline Participation to Majority & Persistent & + & - & $112(48.0 \%)$ \\
\hline Lag Participation & Persistent & - & - & $41(17.6 \%)$ \\
\hline Exploration & Temporary & & & $27(11.5 \%)$ \\
\hline
\end{tabular}

Table 2: Classification of products in diffusion processes (* we have excluded 61 chairs introduced in 1996 and 2005 that show persistent combinations)

\begin{tabular}{|l|c|c|c|c|}
\hline $\begin{array}{l}\text { Classification of } \\
\text { products in the } \\
\text { diffusion processes }\end{array}$ & $\begin{array}{l}\text { Number of } \\
\text { products }\end{array}$ & $\begin{array}{c}\text { Number of } \\
\text { companies }\end{array}$ & $\begin{array}{c}\text { Number of } \\
\text { awards / } \\
\text { Number of } \\
\text { products }\end{array}$ & $\begin{array}{c}\text { Number of } \\
\text { awards / } \\
\text { Number of } \\
\text { companies }\end{array}$ \\
\hline Trend Setting & 37 & 7 & 0.189 & 1.429 \\
\hline Early Adoption & 23 & 8 & 0.042 & 0.750 \\
\hline Participation to Majority & 104 & 8 & 0.077 & 0.250 \\
\hline Lag Participation & 41 & 6 & 0.073 & 0.500 \\
\hline Exploration & 26 & 6 & 0.037 & 0.333 \\
\hline
\end{tabular}

Table 3: Descriptive statistics on Innovativeness

\begin{tabular}{|l|c|c|c|}
\hline Parameter & B & Std error & Sig. \\
\hline (Intercept) & 1.269 & 2.6696 & 0.635 \\
\hline Trend Setting & 1.977 & 0.8141 & $0.015^{* *}$ \\
\hline Early Adoption & -0.165 & 1.2526 & 0.895 \\
\hline Participation to Majority & 0.177 & 0.8382 & 0.833 \\
\hline Lag Participation & $0^{\mathrm{a}}$ & & 0.818 \\
\hline Exploration & -0.288 & 1.2506 & \\
\hline
\end{tabular}

Dependent Variable: Innovativeness; Model: (Intercept), Trend Setting, Early Adoption, Participation to Majority, Lag Participation, Exploration

(*) $\mathrm{p}<0,1 ;(* *) \mathrm{p}<0,05$

(a) Set to zero because this parameter is redundant

Table 4: Logit for Innovativeness and Classification of products in the diffusion processes 


\begin{tabular}{|l|c|c|c|c|}
\hline $\begin{array}{l}\text { Classification of } \\
\text { companies in the } \\
\text { diffusion processes }\end{array}$ & $\begin{array}{c}\text { Number of } \\
\text { products }\end{array}$ & $\begin{array}{c}\text { Number of } \\
\text { companies }\end{array}$ & $\begin{array}{c}\text { Averaged } \\
\text { number of visits } \\
\text { per product }\end{array}$ & $\begin{array}{c}\text { Averaged } \\
\text { number of visits } \\
\text { per company }\end{array}$ \\
\hline Trend Setting & 37 & 7 & 0.47 & 0.59 \\
\hline Early Adoption & 23 & 8 & 0.54 & 0.51 \\
\hline Participation to Majority & 104 & 8 & 0.50 & 0.67 \\
\hline Lag Participation & 41 & 6 & 0.55 & 0.28 \\
\hline Exploration & 26 & 6 & 0.38 & 0.36 \\
\hline
\end{tabular}

Table 5: Descriptive statistics on Consumer preferences

\begin{tabular}{|l|c|c|c|}
\hline Parameter & B & Std error & Sig. \\
\hline (Intercept) & 0.234 & 0.5787 & 0.686 \\
\hline Trend Setting & 0.084 & 0.2268 & 0.710 \\
\hline Early Adoption & 0.008 & 0.2570 & 0.975 \\
\hline Participation to Majority & 0.057 & 0.1844 & 0.755 \\
\hline Lag Participation & $0^{\mathrm{a}}$ & & 0.497 \\
\hline Exploration & 0.168 & 0.5787 & 0.47 \\
\hline
\end{tabular}

Dependent Variable: Innovativeness; Model: (Intercept), Trend Setting, Early Adoption, Participation to Majority, Lag Participation, Exploration

(*) $\mathrm{p}<0,1 ;(* *) \mathrm{p}<0,05$

(a) Set to zero because this parameter is redundant

Table 6: Linear regression on Consumer preferences and Classification of products in the diffusion processes 